\title{
各種病態における周術期管理 \\ 内分泌・代謝系疾患患者の周術期管理
}

\author{
石原弘規*
}

\section{I はじめに}

内分泌・代謝系疾患は多数存在し, 個々の疾患で その麻酔管理も異なるので, 今回はそのなかで特に 遭遇する機会が多いと思われる糖尿病患者とステロ イド投与患者について言及する。

\section{II 糖 尿病}

血糖值の迅速な測定，短時間作用性のインスリ ン, 一定量のブドウ糖投与 $(0.1 \mathrm{~g} / \mathrm{kg} / \mathrm{hr}$ 程度), 輸液ポンプ使用などが広く普及し, 周術期の血糖管 理は以前に比し容易となった。しかし糖尿病患者の 麻酔管理について，従来ややもすると血糖管理にの み目を奪われがちであった，すなわち，麻酔中のイ ンスリンやブドウ糖の投与方法や量に関する論文が 大多数を占めてきた。しかし麻酔中の厳格な血糖コ ントロールの有無により, 糖尿病患者の予後が大き く左右されるか否かについては，明確な回答はいま だ得られていない. 最近, 患者の予後に関して糖尿 病性自律神経障害 (diabetic autonomic neuropathy 以下DAN）が注目されている. 今回, DAN と麻酔の関わり合いについて述べる.

DAN は糖尿病患者の 17〜 40\%にみられ，一度併 発すると， 5 年以内の死亡率は 15～40\%にも達す る ${ }^{1)}$. 胃内容停滞があると 3 年以内に $35 \%$ が死亡す る. DAN は心循環系, 消化器系, 代謝系, 泌尿器 系, など種々の臓器, 器官を障害するが, 心循環機

*弘前大学医学部麻醉科学教室
能反応を用いた標準化された四〜五つの一連の自律 神経機能検査により診断可能である ${ }^{1}$. 通常は二つ 以上の異常があると DAN と診断される。DAN に 起因する障害のうち麻酔管理上は, (1)麻酔中の循環 動態不安定, 術後の心停止を含めた循環系の重篤な 合併症，(2)麻酔前の胃内容の停滞（特に固形物の長 期停滞による誤嚥性肺炎）の二つが特に問題とな る.

(1)に関しては，1978 年に手術直後に心停止症例 が発表されて以来，いくつかの報告がある2) 4).

Burgos ら ${ }^{3)}$ は糖尿病患者では麻酔中低血圧の発 生が $35 \%$ と非糖尿病患者の $5 \%$ に比し，有意に高 いことを報告した。また，徐脈や術後の心循環系合 併症も報告されている. Charlson ら ${ }^{4)}$ は糖尿病患者 のうち $39 \%$ に自律神経障害がみられ, 主に腹部手 術, 血管手術を施行した糖尿病患者 74 人中, 術後 5 人で心停止または心臓死, 15 人に心筋梗塞また は虚血,さらに 8 人でうっ血性心不全が生じたとい う. 5 人の心停止患者に共通している点は DAN を 併発し, 術前心筋梗塞またはうっ血性心不全を有し ている点であり，これらが術前に判明していた患者 では, 術後 3 日以内の心停止発生率は $62 \%$ あっっ た。したがってこのような合併症を併発している症 例では少なくとも術後 3 日はICUなどで集中的に 管理すべきと考えられる。この論文は必ずしも十分 コントロールされた研究でなく, 死亡原因など不明 の点も多く疑問が残るが，少なくても術前に DAN と心循環系障害を有する場合には，術後のリスクが きわめて高いことの警鐘を鳴らすものである．今後 
この方面でのさらなる検討を要する.

DAN 患者で胃内容停滞に起因する誤曣性肺炎の

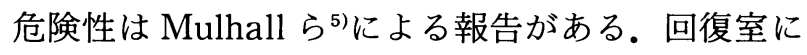
て術前 12 時間以上の絶食後に固形物（人参）を嘔 吐し，嚥下性肺炎を起こした症例を報告している。 電気ショックを施行した DAN 患者でも重篤な誤嬩 が報告されている6)。さらに腎移植を受け糖尿病患 者では非糖尿病患者に比し，胃液量が有意に多いと 報告されている7). しかしわれわれの検討では DAN 患者で麻酔導入時の胃液量増加や $\mathrm{pH}$ の低下 は, 非糖尿病患者や DAN を有しない糖尿病患者と 差はなく,ただ直径 $2 \mathrm{~mm}$ 程度の細かい固形物の頻 度が $31 \%$ と有意に高かった。よって糖尿病患者で 嶼下性肺炎の危険性が高いのは, 胃液量が多く, 胃 液 $\mathrm{pH}$ の低下によるのではなく，固形物が 12 時間 程度の絶食後でも胃内に停滞するためと考えられ た。

多数の細かな固形物の誤嚥は液体より危険性が高 いと考えられるので，十分この危険性を考慮した麻 酔管理が必要である．糖尿病の術前検査の一つとし てこの五つの自律神経機能検査を取り入れることを 提唱したい，検査の詳細については他の論文を参照 されたい1),3),4),8). 特に, 深呼吸 (1 分間に 6 回程 度）時の心拍数変化（正常では R-R 間隔の最大と 最小の差は, 心拍数に変換して $10 \mathrm{BPM} / \mathrm{min})$ は, 選択性は低いものの，スクリーニング検査としては 有用である。

\section{III 急性副腎機能不全}

ステロイド長期投与患者の周術期における急性副 腎機能不全はまれであり，ステロイドカバーなしで も循環不全に陥らず，良好な周術期経過をとること も多い. ステロイドカバーを要した 419 例中 3 例 (0.7\%) のみに不適切なステロイドカバーによる低 血圧がみられたという . 最近われわれは緊急手術 後に高度の循環不全に陥った本症例を経験した ${ }^{10)}$ の で, 症例を提示する。

[症例］ 67 歳の男性. 腹部大動脈破裂で緊急手術
を受け，その後 ICUへ入室した。入室直後明らか に循環血液量低下によると思われる低血圧に陥った が, 輸血, 輸液で回復した. 入室 4 時間後より再び 次第に血圧が低下しはじめ, 輸血輸液の急速大量投 与にも反応せず，不穏状態もみられるに至った。 8 時間目には，血圧が $55 / 33 \mathrm{mmHg}$ まで下降した。 腹部症状やエコー検査では, 後出血は否定的であっ た。さらに中心静脈圧は $6 \mathrm{mmHg}$ であった。低血 圧にもかかわらず，末梢循環はきわめて良好であり 橈骨動脈でも十分脈拍を触知できた。

しかし, 後出血による循環不全を否定するのは必 ずしも容易でなく，血液量が適当か否かを，われわ れが提唱しているブドウ糖初期分布容量（以下 IDVG ${ }^{11)}$ で確かめた。すなわち IDVGの正常值は $130 \mathrm{ml} / \mathrm{kg}$ 程度であり, 血漿を含み血管に富む組 織の細胞外液量を反映し, $100 \mathrm{ml} / \mathrm{kg}$ 以下では著 明な血管内容量低下と考えている.

IDVG 算出は中心静脈よりブドウ糖 $5 \mathrm{~g}$ を 30 秒 で静注し，ブドウ糖投与直前，その後 $3,4,5,7$ 分の血漿ブドウ糖濃度を測定し, ブドウ糖の消退曲 線より 1 分画モデルで求める.

増加した血墏ブドウ糖濃度 4 点から算出したブド ウ糖初期分布容量（以下 IDVG）は $7.22 l(140$ $\mathrm{m} l / \mathrm{kg})$ またブドウ糖投与直前と投与後 3 分の 2 点のみで短時間で推測した IDVGは $7.45 l$ (145 $\mathrm{m} l / \mathrm{kg})$ であり,いずれの值を用いても血管内容 量低下は否定された。

この時点より積極的にカテコラミンを使用した が，ドパミン，ドブタミンには反応せず，エピネフ リン $0.7 \mu \mathrm{g} / \mathrm{kg} / \mathrm{min}$ の投与により, ようやく収縮 期血圧を $80 \mathrm{mmHg}$ 程度に維持できた。この時点で 患者が多発性筋炎に罹患し，15 年間プレドニンを 毎日 $5 \mathrm{mg}$ 投与されており, 手術 3 日前より内服し ていないことが判明した.メチルプレドニソロン 1 $\mathrm{g}$ を静注した直後より血圧は $137 / 62 \mathrm{mmHg}$ とな り，エピネフリンの大量投与より離脱できた.メチ ルプレドニソロン投与直前の血墏コルチゾル濃度は $20.5 \mu \mathrm{g} / 100 \mathrm{~m} l$ であり, 多大なストレス時の正常 
下限 $22 \mu \mathrm{g} / 100 \mathrm{~m} l$ より低く, 副腎機能不全が確認 された. Salem ら ${ }^{9}$ はステロイドカバーの量につい ては従来の量が多すぎると疑問を投げかけており, ステロイド過量による副作用（瘡傷治癒遅延, 免疫 能低下，耐糖能異常など）を軽減するため，少量で よいとしている。軽度の侵襲度（鼠径ヘルニアな ど）ではハイドロコルチゾン相当で $25 \mathrm{mg} /$ 日程度 でよく, 中等度の侵襲度（開腹による胆襄手術な ど）では 50〜 $75 \mathrm{mg} /$ 日を 1 ～ 2 日投与する. 高度 な侵襲度（食道癌手術など）では $100 〜 150 \mathrm{mg} /$ 日 を $2 \sim 3$ 日投与する. 実際には術前に内服している ステロイドを基本的に投与し，そのうえにこの量を 分割追加投与する.

副腎機能不全の臨床所見は非特異的であるが，低 血圧, 末梢血管抵抗低下, 低ナトリウム血症, 腹 痛, 興奮などの精神症状を呈するので, 原因不明の 低血圧がある場合は, 本症発生をも念頭におく必要 がある. 特に今回のように緊急手術で術前の病歴把 握が十分でなかったことは反省させられる。病歴聴 取の重要性をたとえ, 緊急手術といえども強調した い.

\section{IV おわりに}

以上, 糖尿病とステロイド長期投与による合併症 について述べたが, 麻酔科医は単に血糖值, 血圧な どの数值にのみ注目するのではなく, その病態全体 に視点を移し管理する必要がある。

\section{参考文献}

1) Vinik AI, Lizzui FJ, Holland MT, et al. : Diabetic neuropathies. Diabetes Care 16:1926 1976, 1992
2) Page MM, Watkins PJ : Cardiovascular arrest and diabetic autonomic neuropathy. Lancet $1: 14 \sim 16$, 1978

3) Burgos LG, Ebert TJ, Asidda C, et al. : Increased intraoperative cardio-vascular morbidity in diabetics with autonomic neuropathy. Anesthesiology 70 : 591 597, 1989

4) Charlson ME, Mackenzie CR, Gold JP : Preoperative autonomic function abnormalities in patients with diabetes mellitus and patients with hypertension. J Amer Coll Surg $179: 1 \sim 10,1994$

5 ) Mulhall BP, O'Fearghail M : Diabetic gastroparesis: case report and review of the literature. Anaesthesia 39 : 468 469, 1984

6 ) Zibrak JD, Jensen WA, Bloomingdale K : Aspiration pneumonitis following electroconvulsive therapy in patients with gastroparesis. Biol Psychiatry 24 : $812 \sim 814,1988$

7 ) Reissell E, Taskinen MR, Orko R, et al. : Increased volume of gastric contents in diabetic patients undergoing renal transplantation: Lack of effect with cisapride. Acta Anaesthesiol Scand $36: 736 \sim 740$, 1992

8 ) Ishihara H, Singh H, Giesecke AH : Relationship between diabetic autonomic neuropathy and gastric content. Anesth Analg 78 : 943 947, 1994

9) Salem M, Tainsh RE, Bromberg J : Perioperative glucocorticoid coverage. Ann Surg 219: 416 425, 1994

10) Ishihara $H$, Matsuno $S$, Taguchi $S$, et al. : Evaluation of fluid volume status with a glucose challenge test in a patient with acute adrenal insufficiency. J Anesthesia (in press)

11) Ishihara H, Shimodate $Y$, Isozaki $K$, et al. : Relationship between the initial distribution volume of glucose and cardiac output in the critically ill. Canad J Anaesth 40: $28 \sim 31,1993$

\author{
著者連絡先 石原弘規 \\ 厂 036 弘前市在府町 5 \\ 弘前大学医学部麻酔科学教室
}

